\title{
INNER NATURE AND OUTWARD APPEARANCE IN EURIPIDES' ELECTRA
}

\section{Abstract}

This paper presents a new interpretation of Euripides' Electra centred on the issue of hereditary excellence. The question of how nobility is to be defined and recognised forms a unifying theme of this work and is of crucial importance for the development of the plot. It is argued here that nobility is key to understanding two much discussed passages: the great speech of Orestes and the recognition scene.

Key words: Tragedy, Euripides, Greek Poetry, Electra, Orestes

Introduction

Nature ( $\varphi v ́ \sigma ı \varsigma$ ) was an abiding topic of interest for Euripides, as even a cursory study of his plays and fragments will confirm. ${ }^{1}$ 'Nature' refers to the belief that the behaviour of individuals can be determined by inherent character traits that are passed down through families. Though education might play a greater or lesser role in the transference of these characteristics, the Greeks also believed that they were inherited through the bloodline. ${ }^{2}$ Debates on the essence of nature and its identification form the crux of many tragedies, especially those where the noble hero is suffering from unexpected exile or poverty; where his identity (and therefore lineage) is unknown; or where the mettle of a youthful protagonist is still to be tried. In these dramas, the good birth and resulting inner nobility of the hero is either unproven or cannot be easily determined by outward signs, such as wealth or physique.

\footnotetext{
${ }^{1}$ E.g. Heracl. 297-328; IT 609-10; Or. 126-9, 1676-7; Alexander fr. 61b, 61c; Alcmeon in Corinth fr. 75; Antiope fr. 206; Archelaus fr. 231, 232; Bellerophon fr. 285.11-4; Captive Melanippe fr. 495.40-3; Stheneboea fr. 661.1-3; Phoenix fr. 810, 812 (all references to tragic fragments are to $\operatorname{Tr} G F$ ). For studies of $\varphi v ́ \sigma ı s$ in drama see Falkner (1983) 289-300; Conacher (1998); Carlevale (2000) 26-60; Egli (2003) 211-14.

${ }^{2}$ Dover (1974) $83-95$ provides a full list of relevant passages.
} 
Here I suggest that Euripides has structured the action of his Electra around precisely this question of how to determine not just Orestes' identity, but also his innate character and the consequences of such an inheritance.

The issue of the identification of innate character has not passed unnoticed in previous commentaries and discussions of the Electra: Denniston and Cropp, in particular, have provided very full discussions. ${ }^{3}$ Yet its significance for the interpretation of the play has perhaps not been fully realised. I suggest that an understanding of the concept of $\varphi v ́ \sigma i \varsigma$ can provide answers to two problems that are fundamental to our interpretation of the play. First, why did Euripides invent a new character, the farmer, and so remove the action 'from the epic-aristocratic world ... into the realistic world of the fifth century'? ${ }^{4}$ Second, what is the purpose of two apparent digressions: a lengthy speech by Orestes on the identification of good character in human beings (367-400) and an apparently awkward parody of Aeschylus' Libation Bearers in the delayed recognition scene (518-44)?

On the second of these two problems, the simplest but most radical suggestion has been to excise lines $373-9,383-90$ and $518-44$ as irrelevant and, therefore, most probably inauthentic. ${ }^{5}$ Those who prefer less drastic remedies have claimed that the play's supposed defects are in fact deliberate. In arguing against the proposed deletion of 518-44, Lloyd-Jones contented himself with observing that a parody of Aeschylus does not need to 'expedite the action of the play' if ridicule is its main or only aim. ${ }^{6}$ Alternatively, Goff has interpreted the

\footnotetext{
${ }^{3}$ Denniston (1939) 80-2; Cropp (2012) 2-3; see also Egli (2003) 225-7.

${ }^{4}$ Webster(1971) 34. On the methodological problems with applying the term 'realism' to the play, see Goff (2000).

5 The authenticity of 373-9 and 386-90 was first questioned by von Wilamowitz-Moellendorff (1875) 190-3; that of 518-44 by Mau (1877) 291-301, a suggestion revived by Fraenkel (1950) III 821-6. For recent summaries and bibliography see Cropp (2012) 161-2, 180 and Distilo (2012) 163-72.

${ }^{6}$ Lloyd-Jones (1961) 179. On parody in Euripides, see Davies (1998) 395-400. Cropp (2012) 176 nevertheless deems humour alone as a 'weak explanation' for the oddities of lines 518-44.
} 
'perverse anagnorisis' by means of the scar as an explicit 'invitation to the audience to "recognise" the scene's poetic pedigree'. ${ }^{7}$ In her recent study of metapoetry in Euripides, Torrance has similarly viewed the recognition scene in the Electra as an 'invitation to reflect on the conventions of dramatic production' ${ }^{8}$ Wohl echoes this approach in pointing out that the play raises and then seemingly dashes the prospect of a demotic hero in the farmer. The purpose of this volte-face is, she assumes, to show the limitations of a genre dedicated to the glorification of aristocratic heroes. ${ }^{9}$ From this perspective, the problem is not textual but a failure to understand the play's metapoetics.

Halporn and Cropp, however, have stressed that, though Euripides may well be evoking previous versions of the myth, all parts of the text should nevertheless be relevant to the development of the plot in some way. ${ }^{10}$ What is needed is a coherent scheme or structure that might excuse the play's eccentricities and explain elements seemingly unmotivated by the plot. ${ }^{11}$ Some have supposed that Euripides' aim was to develop (and potentially highlight deficiencies in) the psychological character of his dramatis personae, an approach which has been endorsed most recently in Van Emde Boas' examination of language and characterisation in the Electra. ${ }^{12}$ Cropp points out that Orestes' apparently 'snobbish and superficial' musings on the criteria for nobility are in fact both a necessary part of his disguise and, ironically, a set of standards 'applicable to his own conduct [that] will be

\footnotetext{
${ }^{7}$ Goff (1991) 261; cf. Goff (2000) 93.

8 Torrance (2013) 15.

${ }^{9}$ Wohl (2015a); (2015b) 62-85; cf. Michelini (1987) 229-30.

${ }^{10}$ Halporn (1983) 105-6; Cropp (2012) 176.

${ }^{11}$ See e.g. Morwood (1981) 368 for a 'pattern from allure to destruction'.

12 Van Emde Boas (2017) 61-2; on the negative portrayal of Electra see: Kitto (1939) 334 'callous to the verge of insanity'; Gellie (1981) 2-3: 'very ordinary and silly'; on Orestes see Denniston (1939) xxvii 'an unattractive character'; Kitto (1939) 338 'no bold hero'; Tarkow (1981) 147; Raeburn (2000) 155-6; on the deficiencies of such approaches, see however Lloyd (1986) and Michelini (1987) 187-98.
} 
recalled when the matricide is revealed at the end as a pitiless and ignoble act.' ${ }^{13}$ Similarly, for Goldhill the 'trite' and 'clumsy' rhetoric of Orestes in lines 367-400 is deliberate and central to his characterisation. Its overall purpose is to prompt the audience into questioning the heroes of myth, just as for Wohl the 'empty heroism' of Orestes, when compared to the farmer, is intended to show that elitism is equally 'just an empty form' ${ }^{14}$ In the case of Electra at 518-44, Gallagher believes that her 'sophistic' and ultimately erroneous logic looks forward to her later arguments for matricide and their disastrous consequences. The supposed parody has as its primary target not Aeschylus, but Electra herself and her model, the sophists. ${ }^{15}$

Here I would agree with those who assert that Orestes' speech and the recognition scene are both textually sound and integral to the plot. However, I suggest that this is a play less concerned with characterisation than what the Greeks would term character, that is the marks of inherent nature and the consequences that follow from being, and being identified as, a noble man. In the recognition scene of Aeschylus' Libation Bearers, Orestes' only concern is to establish his identity. For Euripides, the question of identity is linked in the Electra with the problem, equally common in tragedy, of determining a person's nature.

1. Nature: what does it mean and why does it matter?

The part of nature $(\varphi v ́ \sigma 1 \varsigma)$ that matters most in Greek tragedy consists of moral qualities. The heroes of tragedy are those who are inherently and unavoidably good men and women. The

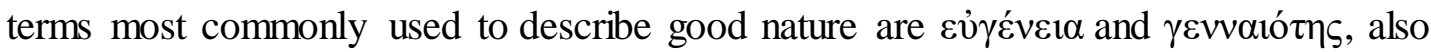
translated here as 'nobility'. Aristotle defines the former as specifically 'being of good birth',

\footnotetext{
${ }^{13}$ Cropp (2012) 7; cf. Van Emde Boas (2017) 165-9.

${ }^{14}$ Goldhill (1986a) 165, 170; Wohl (2015a) 69-70; cf. Tarkow (1981) 144, on Euripides' desire to depict Orestes as 'fundamentally unheroic'. On Orestes' sophistic rhetoric, see also Egli (2003) 227.

15 Gallagher (2003).
} 
and the latter as the quality of 'not departing from one's own nature ( $\varphi v ́ \sigma ı)$ ', be it good or bad. ${ }^{16}$ This 'good birth' or 'nature' is demonstrated by certain patterns of behaviour. Among animals, for example, the lion exhibits a brave, free and 'noble' character ( $\tau \dot{\alpha} \delta$ ' $\dot{\lambda} \lambda \varepsilon v \theta \varepsilon \dot{\varepsilon} \rho 1 \alpha$

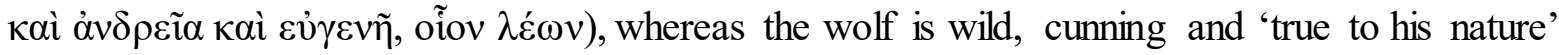
(

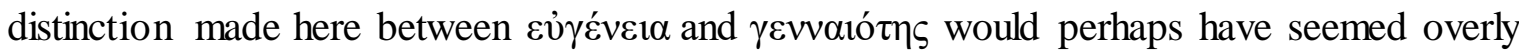

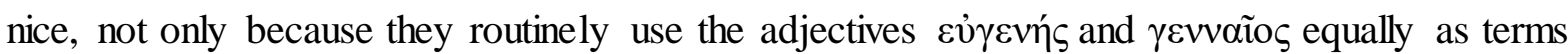
of approval, but also because a protagonist of good birth aims to remain true to that nature. ${ }^{17}$ In either case these terms may designate individuals as those who are both morally and naturally good and who instinctively behave in a manner befitting their breeding.

Aristotle's lion finds many parallels among the heroes of tragedy. Their good birth means they are good: brave and strong, but also indefatigably loyal to friends and unable to act in a shameful manner. Those who come short of this demanding code of behaviour are dismissed as bad men (какоí). Aeschylus has Eteocles describe the Theban Melanippus in just such a manner:

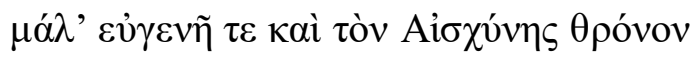

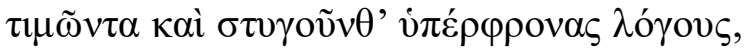

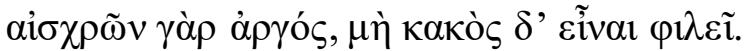

One truly well born who honours the throne of Shame and hates arrogant words, for he is idle in deeds of infamy and desires not to be a bad man.

(Sept. 409-11)

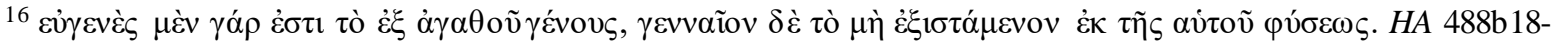
20; cf. Rhet. 1390b21-3.

${ }^{17}$ For $\gamma \varepsilon v v \alpha i ̃ o \varsigma$ as a complimentary term, see Aesch.Ag. 613-14, 1305, Eum. 625; Soph. Aj. 1355, El. 129, 287, OT 1469, Trach.308-9, Phil. 50-1, 475-6, 1068, OC 7-8, 569, 1042-3, 1636-40; Eur. Hec. 591-2, Ion 237-40, Or. 1060-4, frr. 232, 329, and 1066.
} 
Iphigenia in Euripides' Iphigenia in Tauris reacts to Orestes' determination to die for his friend by similarly praising his good birth and nature:

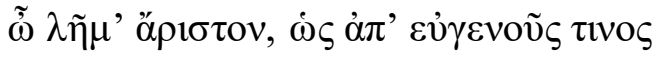

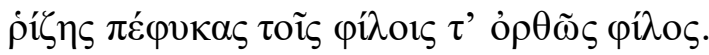

Oh stout heart, indeed you are grown from some noble stock, a true friend to your friends!

(609-10)

This mindset can lead to disaster for the hero and those around him, as in the case of Hippolytus, who according to Artemis was destroyed by his nobility ( $\tau$ ò $\delta$ ' $\varepsilon v ่ \gamma \varepsilon v \varepsilon ́ \varsigma \sigma \varepsilon \tau \tilde{\omega} v$ $\varphi \rho \varepsilon v \tilde{\omega} \nu \alpha \dot{\alpha} \omega \dot{\lambda} \varepsilon \sigma \varepsilon v$, Hipp. 1390). But even in the face of suffering and death, tragic protagonists cannot act in a manner contrary to this inherent nature: a disposition that is summed up in the pithy maxim of Ajax that 'to live well or die well is what a well-born man must do'. ${ }^{18}$ Knox termed this attitude the 'heroic temper'. ${ }^{19}$ Although he believed it to be most clearly shown in Sophocles' heroes, it would be a mistake to view the inner nature that forms the basis for the 'heroic temper' as something uniquely Sophoclean. Rather, as we shall see, the idea of a heroic nature is equally central to many of the plays of Euripides.

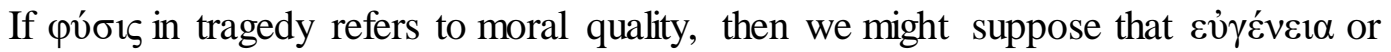
$\gamma \varepsilon v v \alpha i$ ínৎ should as readily mean 'noble in character' as 'noble in birth'. Yet moral character is not the result of chance or choice, but of good parentage. As the child of good fathers, a character in Euripides' Archelaus (probably the Heraclid Archelaus himself) gives

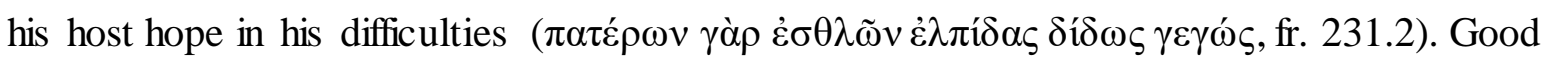
behaviour on the part of the hero reveals, and is explained by, good family background.

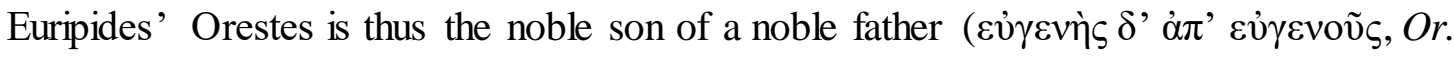

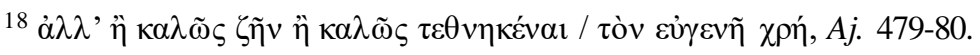

${ }^{19}$ Knox (1964), especially 1-27.
} 
1676), while in the Rhesus Hector is 'an excellent son of an excellent man' ('̇ं $\theta \lambda$ ò $\varsigma \dot{\varepsilon} \sigma \theta \lambda \mathrm{o} \tilde{v}$ $\pi \alpha \tilde{i}, 388)$. Neoptolemus in Sophocles' Philoctetes is similarly styled as the son of an excellent

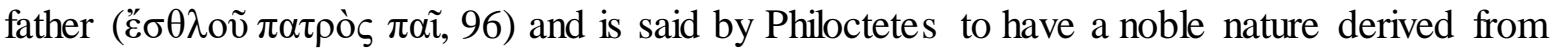

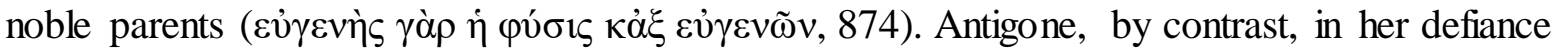
of Creon, demonstrates to the chorus savage breeding derived from a savage father ( $\tau$ ò

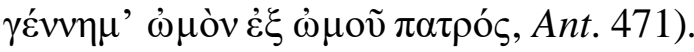

All these examples betray a strong conviction that good parents should give birth to good children, as a character in Euripides' Alcmaeon in Corinth makes clear:

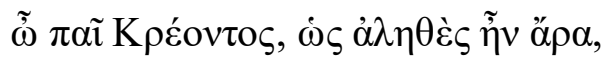

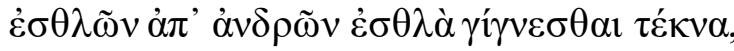

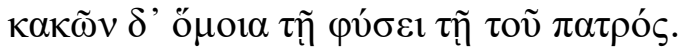

Oh child of Creon, how true indeed it is that from good men are born good children, but from bad men come offspring similar to the nature of their father.

This same conviction leads a speaker in Euripides' Antiope to urge all mankind to sire noble

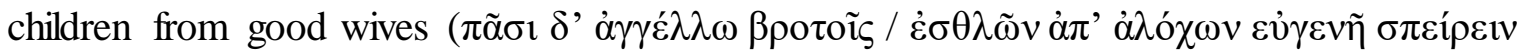
$\tau \varepsilon ́ \kappa v \alpha$, fr. 215). Good character is thus something fundamentally concerned with hereditable nature.

It might be objected that 'good birth' is in fact a specious claim made only by families that have maintained their standing in society over more than one generation. This is certainly a possible argument, made in particular by a speaker (probably Macareus) in Euripides'

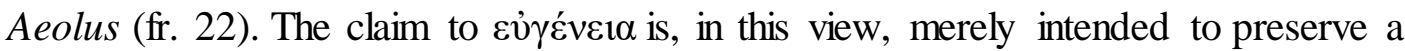




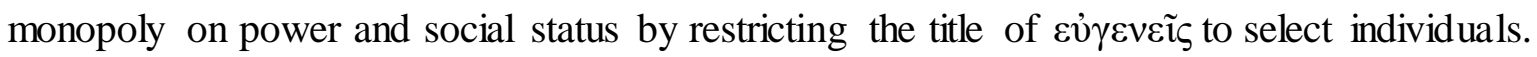
Nobility is thus determined by wealth, social connections and appearance. ${ }^{20}$

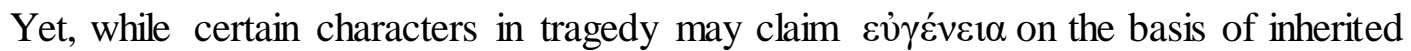
wealth or power, this does not overturn the principle that nobility is an inherited moral quality. The Greeks, in fact, distinguished between those who were accounted noble and those who were actually and morally noble by nature. There is no inherent link between wealth or position and moral character, though those who are of good birth, such as the children of Heracles in Euripides' Heraclidae (232-5), may deserve better fortune on account of their lineage. In fact, in tragedy the well-born can appear as indigent outsiders. ${ }^{21}$ The prologue of Euripides' Bellerophon comments on three distinct sorts of people: the ignoble rich man, the poor man of good birth, and the pauper who has neither wealth nor nobility (fr. 285.3-5, 11-13).

Moreover, in several plays by Euripides protagonists assert that good birth endures in poverty and exile. ${ }^{22}$ The truth of this claim is seemingly proven when heroes who have suffered a reverse in fortune show their innate breeding. In Euripides' Alexander, the poor herdsman who should be of poor breeding performs better than many of the nobility. The chorus note that nobility is a moral quality and not a matter of wealth (fr. 61b), yet it will eventually be revealed that the herdsman is also a son of Priam. The courage and strength of the sons of a slave woman in Captive Melanippe prompt a similar reflection from a messenger (fr. 495.40-3). He reports that they have killed the brothers of a queen, but these boys are also the sons of Poseidon. The charcoal-burner Syrus in Menander's Arbitration

\footnotetext{
${ }^{20}$ Eur. Ion 237-40; Aeolus fr. 22; Erechtheus fr. 362.13-15; cf. [Xen.] Ath. Pol. 1.2 and 1.4; Arist. Pol. 1301b1-

4; Plut. Lys. 2.1.

${ }^{21}$ Eur. Archelaus fr. 232; Danae fr. 326; Thyestes fr. 395.

${ }^{22}$ Eur. Hec. 596-8; Archelaus fr. 232; Temenidae fr. 739; fr. 1066
} 
similarly fears that a recently exposed baby may turn out to be of noble birth and so in time

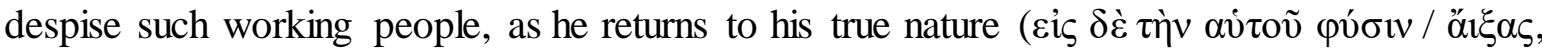
322-3). He adds that such plots are typical of tragedy (325-6). The earliest representation of this type, however, is Eumaeus in the Odyssey (15.403-84), the virtuous swineherd who, it transpires, is also a king's son kidnapped by Phoenician traders.

Those excluded from power are thus still able to claim good lineage. Ajax, the son of the Aeacid Telamon, is of impeccable birth but is accounted a mere demesman by the ruling sons of Atreus (óv $\delta \rho \alpha \delta \eta \mu$ ó $\eta v, A j .1071)$. Parallels might include Eetion, the father of the tyrant Cypselus, who was both a 'member of the demos', and thus excluded from the ruling

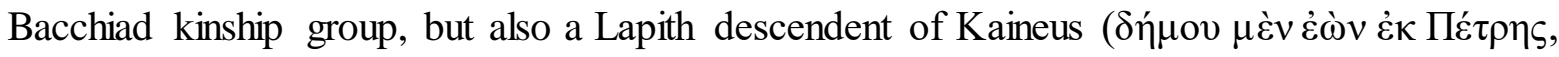

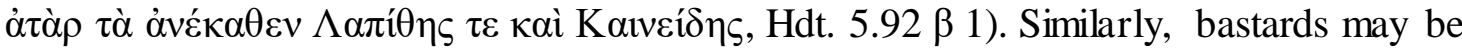
deemed of lower social status than legitimate sons, but if they are born of a good father they may inherit his qualities. ${ }^{23}$ The virtuous Teucer of Sophocles' Ajax is a key example:

Menelaus and Agamemnon dismiss him as the son of a concubine, but he can point to the fact

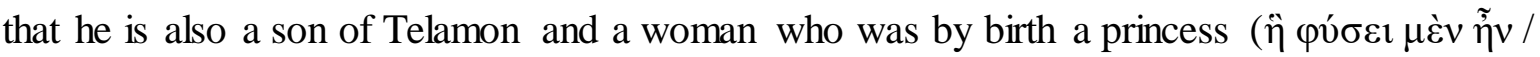
$\beta \alpha \sigma i$ $\varepsilon \varepsilon 1 \alpha, 1301-2)$. The sons of Atreus, though they may claim good birth, have not inherited

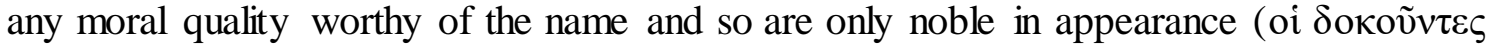

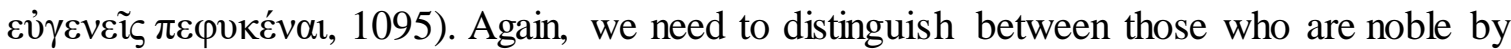
nature ( $\varphi v ́ \sigma \varepsilon \imath)$ and those who are called noble by convention (vó $\mu \omega)$.

A second objection is that the children of good parents can turn out to be bad. Once again, however, it does not disprove the overall principle that excellence is hereditary. First, it is accepted that the natural transference of good character can fail to take place, much as a harvest can occasionally fail in previously good soil, and so a good family is not an absolute

\footnotetext{
${ }^{23}$ Eur. Eurystheus fr. 377; Soph. Aleuadae fr. 87.
} 
guarantee of a good nature. ${ }^{24}$ Demophon in Euripides' Heraclidae proves, through his treatment of the children of Heracles, that he is no less a man than his father Theseus, but Iolaus indicates that sons rarely equal their fathers in the same way (324-8). For Antigone, Ismene's behaviour will determine whether she is truly noble or a bad woman anomalously

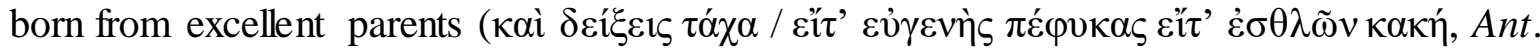
$37-8)$.

Second, it is accepted that nurture has some role in the formation of character alongside nature. Ajax assumes that Eurysaces, as his son, will show no fear at the sight of

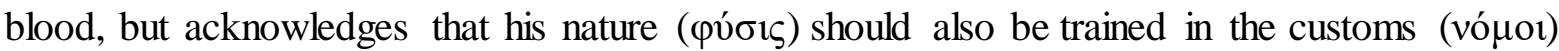
of his father. ${ }^{25}$ Nurture may thus make a person worse or better than they should be by nature. ${ }^{26}$ In Euripides' Antiope, Zethus believes that the skill of lyre playing has this very effect:

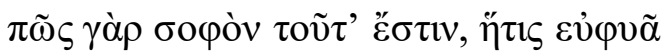

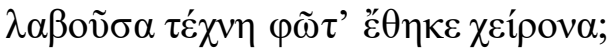

How can this be a form of wisdom, a skill that takes a naturally good man and makes him worse.

In the same way, Sophocles' Neoptolemus is led astray by Odysseus and, as Philoctetes

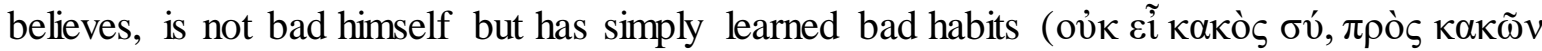

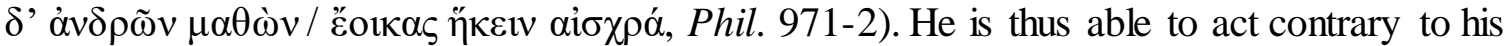
nature, even though it pains him to do so and even if, in time, his nature will eventually

\footnotetext{
24 See Arist. Pol. 1255a39-b3; Rhet. 1390b24-31.

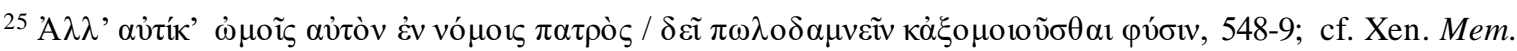
4.1.3 on how the best natures need training most.

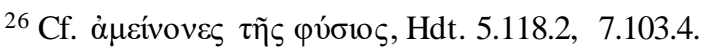


reassert itself (902-3). On the other hand, while it is accepted that the wrong education can make someone worse, no one who is by nature wholly bad (какós) can be made good through education. ${ }^{27}$ This is broadly accepted as a fact not just by the heroes of tragedy, but even by the professional teachers of classical Greece, such as Isocrates (15.185-7). On this basis, Hippolytus (Hipp. 78-80) can reserve the grove of Artemis for those who are untaught but naturally good ( $\dot{\varepsilon} \vee \tau \tilde{n} \varphi v ́ \sigma \varepsilon \imath)$, a concept that is well known also from the odes of Pindar. ${ }^{28}$ The consequences of one's birth can be avoided temporarily, but eventually better instruction gives way to nature, just as the tame lion cub must in time inherit the character of a murderous beast from its parents (Aesch. Ag. 717-36).

Nature (and good birth or nobility), then, is a set of inherited moral characteristics that can determine behaviour. For both Euripides and Sophocles this was a useful concept around which to develop a dramatic plot. First, tragedy is concerned with mighty individuals with super-human characteristics that are frequently the cause of their destruction. This 'heroic temper' can be explained as the result of descent from still greater forebears and even gods. Second, since well-born men and women can be found even among the victims of misfortune and poverty, nobility can be hidden, as even a slave or beggar can be a prince or princess in disguise. The revelation of a noble identity thus forms the basis for several of Euripides' plays, such as the Alexander, Telephus and, as we shall see, Electra. Finally, because the inheritance of good qualities from parents to children is not guaranteed, a major question for characters who are young and untried is whether they are worthy of their fathers. In these cases, they must show that their nature is in fact the same as their forebears. Neoptolemus

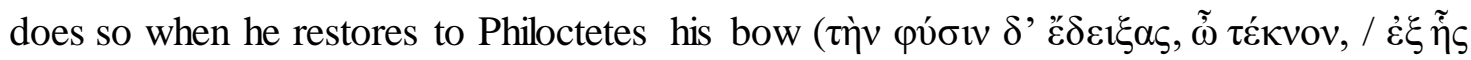

\footnotetext{
${ }^{27}$ Eur. Hipp. 916-22; Hec. 591-8; Peleus fr. 617; Phoenix fr. 810; fr. 904; Soph. fr. 808; cf. Dem. 21.150 on Meidias' inherently bad character and consequently suspect lineage.

${ }^{28}$ Ol. 2.86; 9.100-101; Nem. 1.25; Rose (1974) 151-3.
} 
๕ै$\beta \lambda \alpha \sigma \tau \varepsilon \varsigma$, Phil. 1310-11). Similarly, in Euripides' Orestes the hero aims to show his nature

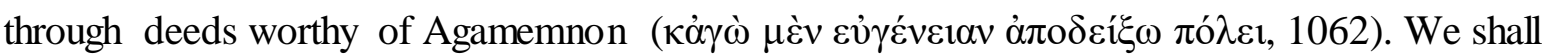
see that much the same concerns with revealing and identifying character govern the action of the Electra.

\section{The Prelude to Recognition}

Returning now to the Electra, the play may be divided roughly into three sections, each of which contributes to and makes inevitable the final tragic departure of Orestes and Electra. The first (1-486) forms a prelude to the recognition scene, the purpose of which is to establish the basic principles that will determine the action of the two subsequent sections - the recognition (487-595) and revenge (596-1359) - and their consequences. These principles are

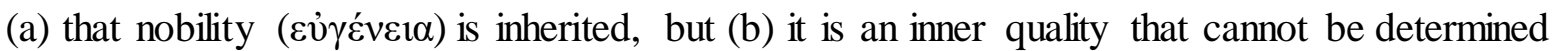
by outward appearance, and (c) that the inheritance of good family characteristics is not guaranteed but must be proven by actions and behaviour.

The farmer opens the play and his speech directly introduces the question of $\varphi v ́ \sigma i \varsigma$ that will dominate the subsequent episodes. Electra, the unwedded princess of myth, has found herself in a humble cottage married to a poor farmer. The reason for this, we are told, is Aegisthus' regard for hereditary excellence: he is afraid that Electra may mate with a noble

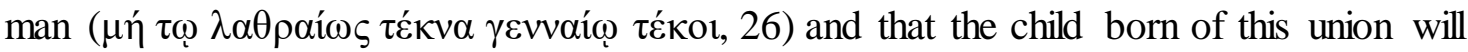
inherit the strength to become Agamemnon's avenger. Prevented from killing Electra, Aegisthus tries to solve this problem by marrying her off to an obviously weak and ignoble citizen, the logic being that a weakling will beget in turn a weak son ( $\dot{\varsigma} \varsigma \dot{\alpha} \sigma \theta \varepsilon v \varepsilon \tilde{c} \delta o v ̀ \varsigma \dot{\alpha} \sigma \theta \varepsilon v \tilde{\eta}$

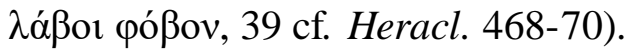

Here Aegisthus assumes that the strong, and therefore noble, are identical with the wealthy. In fact, as we have seen, a rich man can lose his wealth, but he cannot easily change 
his nature. It is precisely this point that Electra will later make in her address to Aegisthus' corpse:

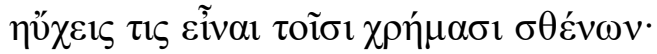

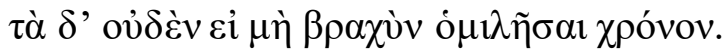

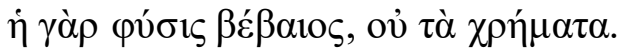

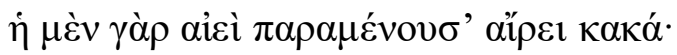

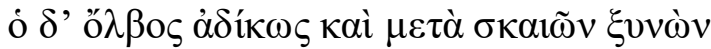

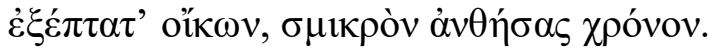

You used to boast in being someone strong in wealth, but this is worthless except in the short time it abides with you. For nature $(\varphi v ́ \sigma 1 \varsigma)$ is secure, not wealth: the one endures with you forever and alleviates misfortune, while wealth dwells unjustly with fools and flies from the house after flourishing for a short time.

The farmer actually has a hidden noble pedigree, and therefore has, at least potentially, inherited inner excellence.

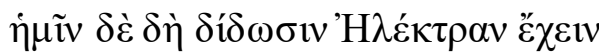

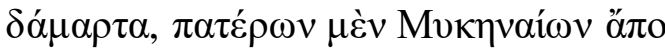

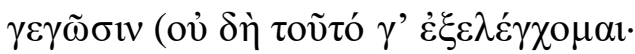

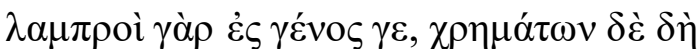

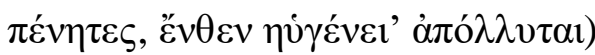

To me, one born from Mycenaean ancestry, he gave Electra to have as my wife (for I cannot be faulted in this at least: my ancestry is impeccable, but in possessions I am

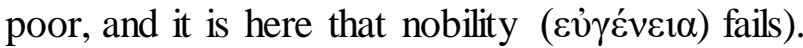


Although he lacks the riches of the nominally well-born, his future actions will show that the farmer's bloodline has endured the wreck of his family's fortunes.

Some scholars have focussed on how the speech develops the farmer's character. Denniston, for example, noted that 'the Farmer is pleasantly drawn: a little self-conscious and priggish, perhaps, but honourable, warm-hearted, and considerate. ${ }^{29}$ Yet, in emphasising characterisation, we may overlook the connection between the prologue and the developing theme of hidden nobility, as well as its consequences for the plot. Euripides is careful to undermine any suspicion that the farmer is a pompous fool. If, as the farmer suggests (50-3), he seems foolish to some in not consummating his marriage, the true fool is the one who judges by appearances. He is genuinely noble and the blood of his ancestors, unlike their wealth, has not been lost in transition down the generations. We should not be surprised at the appearance of a man of hidden good birth in the costume of a peasant, since, as we have seen, this is a common feature of Euripidean tragedy.

If the farmer is not a fool, then neither is he a coward: the other explanation for his conduct suggested by Orestes (260). Electra insists that, though he may be concerned about how Orestes will react to news of his sister's marriage, the real reason is that he is inherently

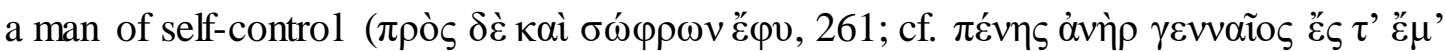
$\varepsilon \dot{\sigma \varepsilon \varepsilon \beta \eta ́} \varsigma$. 253). Orestes agrees: the farmer is a man 'of good breeding' ( $\gamma \varepsilon v v \alpha i \tilde{o} v$ ö $v \delta \rho$ ' $\varepsilon \tilde{\varepsilon} \lambda \varepsilon \xi \alpha \varsigma, 262)$. Any remaining doubts are removed by his behaviour towards Orestes and Pylades. Despite his poverty, he refuses to act in the manner of a man of 'poor breeding' and

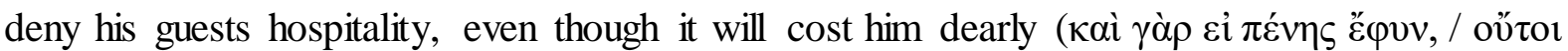

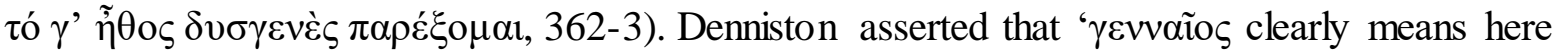

\footnotetext{
${ }^{29}$ Denniston (1939) xxxi; this view is echoed by Cropp (2012) 137 and Van Emde Boas (2017) 79. See, however, Yoon (2012) 98-105, who argues that the farmer's function and characterisation is more limited.
} 
"noble-minded" ... not "nobly-born". The farmer has good blood in his veins, and is proud of it, but Electra regards him as an ordinary plebeian'. ${ }^{30}$ To some extent this is true, since as one who has only lately declined in status she regards him as her social inferior. Yet the fact remains that the farmer is morally noble due not to money, or the lack of it, but to hereditary virtue.

The appearance of Electra develops this same theme in similar ways. She is also noble, but unlike the farmer her family's misfortunes are recent and her lineage is well known. The farmer begins his prologue with the substantial achievements of Agamemnon at Troy (2-7). This victory is evidence of good blood within the family and will provide a precedent for Orestes' later triumph over Aegisthus (206, 336-8, 880-2). However, Electra does not look like the daughter of a man of nobility and power, as she tells the chorus of maidens:

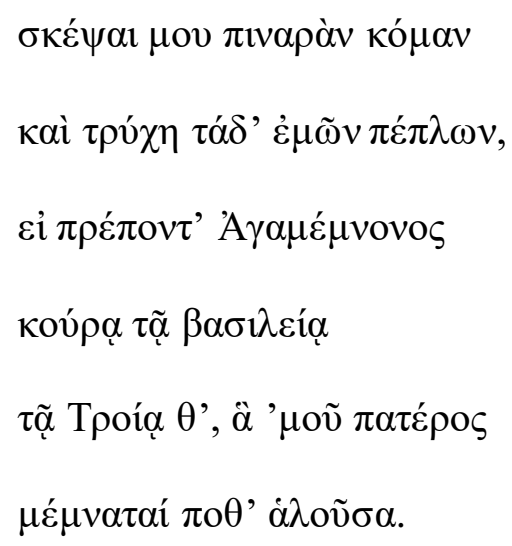

Look at my dirty hair and these raggedy dresses, judge if they are fitting for the royal daughter of Agamemnon and for Troy, who remembers her capture at the hands of my father.

\footnotetext{
${ }^{30}$ See Denniston (1939) 81; cf. 80 on 253:
} 
Electra's concern for her personal appearance (and her refusal to do anything about it by borrowing clothes from the chorus) has sometimes been viewed as a sign of weak character: she is a bitter snob who simply loves to complain. ${ }^{31}$ As with the farmer, however, Euripides' concern is not exclusively the characterisation of one dramatis persona, but rather the development of a key theme that will run through the play to its conclusion. As Lloyd has argued, her reasons for continuing to live in squalor are perfectly intelligible within the context of the action: she is in mourning and, moreover, she wishes her lament to be a reproach on her enemies (just as in Sophocles' treatment of the myth). ${ }^{32}$ It is more important for the development of the plot that she should not resemble a 'noble' woman, just as the farmer does not appear to be noble. In her present state, she is unrecognisable as a child of Agamemnon: so much so that Orestes assumes that the mournful girl approaching him, dressed in rags and carrying a water jar on her shaven head, is a slave (107-11). Electra's pot is indeed, as Raeburn argues, a significant stage property, but its purpose is not primarily to indicate her poor character, but rather the inconsistency between Electra's appearance and her known pedigree. ${ }^{33}$ This prop will provide a stark contrast to the sumptuous finery of Clytemestra (966, 1139-40), a woman who has demonstrated her true inner character through the killing of her husband.

The contrast between, on the one hand, the farmer's actions, which reveal nobility, and, on the other, his appearance, which serves to hide this inner worth, leads Orestes

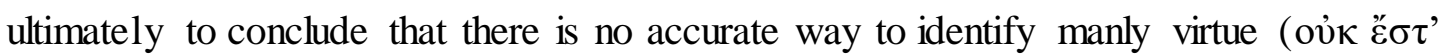

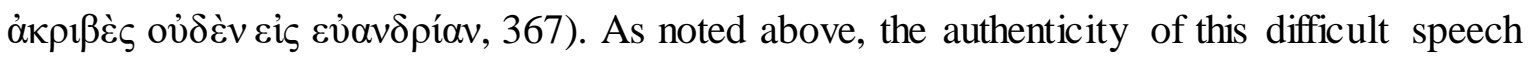
(367-400) has been questioned, especially lines $373-9$ and $386-90 .{ }^{34}$ In terms of language and

\footnotetext{
${ }^{31}$ See n. 12, with Raeburn (2000) 152-4 and Yoon (2012) 99-103.

${ }^{32}$ Lloyd (1986) 6-7; cf. Michelini (1987) 188.

33 See n. 33.

34 See n. 5.
} 
style the speech is at least passable. ${ }^{35}$ The three principal objections therefore concern their apparent irrelevance, repetition (Orestes appears to comment on the inadequacy of wealth as a criterion for nobility in both 371-2 and 373-6, and of martial prowess in 377-9 and 387-90), and the fact that Diogenes Laertius attributes line 379 to the Auge. As is demonstrated elsewhere, the last two are not serious enough on their own to warrant deletion and need not detain us here. ${ }^{36}$ The third, irrelevance, is more concerning. In what follows, I shall attempt to demonstrate that the speech is not merely a rhetorical set-piece: rather the questions it raises are significant for the development of the plot.

Some critics have viewed the speech as an attack on the very principle of the hereditability of moral qualities. According to Wohl, the speech 'undercuts one of the traditional props of elitism in Athens: the belief that aristocratic birth predicted moral worth and that wealth was its divine reward'. ${ }^{37}$ The farmer's behaviour points to 'a "reality" in which a man's worth is judged only by his character, not by external tokens like wealth or birth'. ${ }^{38}$ Others have been equally willing to interpret the speech as a radical renunciation of previous assumptions. Basta Donzelli called the farmer 'il campione della nuova eugeneia', while Michelini alluded to 'the new standard of heroism offered by the Autourgos' ${ }^{39}$ Yoon has similarly argued that the farmer's qualities, which are 'not for the most part "heroic", highlight tensions between 'conventional tragic ideals and the mundane realities' in which the

\footnotetext{
35 Pace Reeve (1973) 152-3, on the use of $\gamma$ áp in 380; see Goldhill (1986a) 159 for a response. Slings (1997) 146 suspects that the lines are authentic, even if the style is 'not Euripides at his best'. and the new classes which were then rising to prominence under the democratic system of government at Athens'.
} 
protagonists find themselves. ${ }^{40}$ Yet this interpretation is unsatisfactory, since in the play character is determined precisely by birth. All the characters are in complete agreement on at least this one issue: that excellence is inherited, as it always has been. In fact, there is nothing particularly new about the farmer's hidden nobility or the problem it poses, since he differs little from the disguised or impoverished heroes of other Euripidean tragedies. Orestes merely reaffirms the (in tragedy) well-established truth that good birth will endure vicissitudes of fortune.

Orestes does begin by acknowledging that family background, even when it is known, is not necessarily an indication of good character. The natures of men are muddled ("丷 $\chi 0 v \sigma \mathrm{l}$

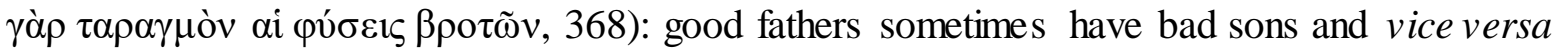
(369-70). This is not a repudiation of the doctrine of inherited excellence, but in fact, as we have seen, it only proves that good breeding may skip a generation or diminish entirely. Denniston correctly interpreted these lines when he claimed that 'all Orestes says is that the

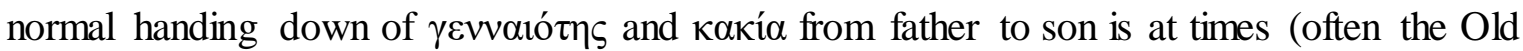
Man says at 551) surprisingly interrupted. ${ }^{41}$ The prime example of someone from a good family who has not inherited good character is Clytemestra: as Electra confirms, she

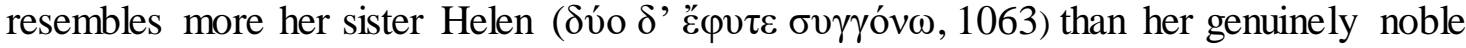
brother Castor. This awareness did not prevent, and does not contradict, Electra's earlier

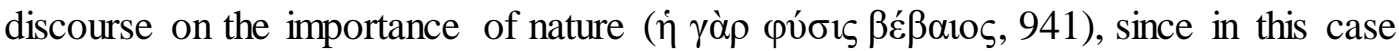
Clytemestra's wickedness is explained by her blood relationship with Helen. Similarly, nothing in Orestes' oration seriously challenges the premise that nobility is inherited. What it does do is establish an additional premise: that nobility is hard to identify.

\footnotetext{
40 Yoon (2012) 99, 105.

${ }^{41}$ Denniston (1939) 93.
} 
Orestes continues to outline the problem by focussing on another difficulty: like the farmer, the good can be poor, while the bad can be rich.

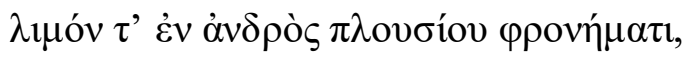

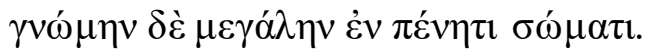

I have beheld dearth in the mind of a rich man, and great thoughts in a poor body.

This again is entirely typical of Euripides and recalls the poor heroes of his other dramas. The contrast between the inner mind of the rich man and the body of the pauper alerts us to the fact that wealth is an outward symbol, whereas it is inner worth that matters. The same is true of Orestes' choice of word for 'virtue' ( $\varepsilon u ̉ \alpha v \delta \rho i ́ \alpha)$ at 367. This could be treated as a physical quality that could be assessed in terms of stature and beauty, as at the contests for củavopía held at the Panathenaea and elsewhere. Yet Orestes here stresses that it is in fact a moral virtue that cannot be identified easily. ${ }^{42}$ As Van Emde Boas remarks, 'Orestes is concerned not so much that there are no signs whatever that can help in ascertaining $\varepsilon v ่ \alpha v \delta \rho i ́ \alpha$, but ... that there are no outward and easily discernible signs.' 43

Now that Orestes has explained the nature of the problem, he continues by suggesting, and then abruptly dismissing, common yard sticks for nobility (to borrow the farmer's

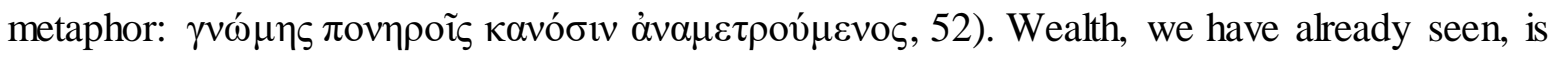
an external sign that does not necessarily reflect natural interior worth. Orestes adds that the same is true of poverty, for though good men can be poor, poverty is not itself a good and can

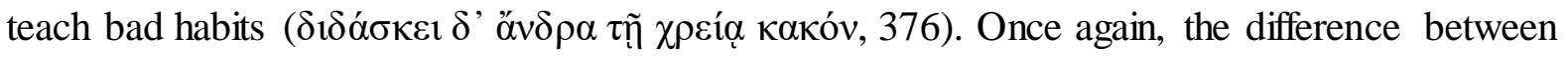

\footnotetext{
${ }^{42}$ For $\varepsilon \dot{v} \alpha v \delta$ pí $\alpha$ as moral virtue cf. Eur. Supp.911-15; for the contest at the Panathenaea see $I G \mathrm{II}^{2} 2311.75$ and And. 4.42; at the second century Theseia see $I G \mathrm{II}^{2}$ 956.48; in general see Xen. Mem. 3.3.12-13; Athen. 13.565f; Crowther (2004) 334-6.

${ }^{43}$ Van Emde Boas (2017) 178-9.
} 
nature and education and the primary importance of nature, which education can either improve or mar, is emphasised.

Orestes then considers another symbol of nobility: physical courage in battle ( $\dot{\alpha} \lambda \lambda$ ' $\varepsilon i \varsigma$ ö $\pi \lambda$ ' $\dot{\varepsilon} \lambda \theta \omega ́ v ; 377)$. Again, Orestes dismisses this test, though not the importance of martial valour itself, because it is unreliable: how can a man already engaged in battle see which of his companions is fighting well (377-8)? Physical courage remains an element of nobility and will prove essential in the killing of Aegisthus (itself a form of combat and judged worthy of comparison to Agamemnon's victory at Troy). The problem is that there is no way of measuring warlike prowess.

Orestes abandons these signs of nobility and explains that the farmer's conduct has ultimately led him to this conclusion. He then proposes a final sure test: a person's character

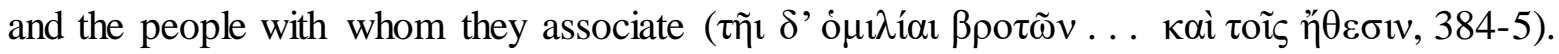
The farmer has just denied that he possesses an ignoble character ( $\tilde{\eta} \theta 0 \varsigma \delta v \sigma \gamma \varepsilon v \grave{\varepsilon} \varsigma, 363)$ and has shown this to be the case through his generosity. A good person should, furthermore, only associate with people of his own kind. By contrast, those who are bad enjoy the company of the bad. ${ }^{44}$ These criteria are less immediately obvious but still observable signs of inner nature.

Lines 386-90 have proven hard to interpret and even the speech's defenders struggle to explain their relevance. ${ }^{45}$ Due to similarities with fr. 282 , a polemic against athletes from Euripides' satyr play Autolycus, some critics have perhaps been too eager to dismiss these

\footnotetext{
${ }^{44}$ Cf. Eur. fr. 812.7-9; Thgn 597-8, 1243-4.

${ }^{45}$ Reeve (1973) 152 expresses this view most forcefully: '[the] reflexion on the superiority of moral to physical strength [is] irrelevant, and no more words need be wasted on [these lines].' See also Denniston (1939) 97;

Goldhill (1986a) 169-70.
} 
lines as an irrelevant digression on a common theme. ${ }^{46}$ The men criticised in both passages

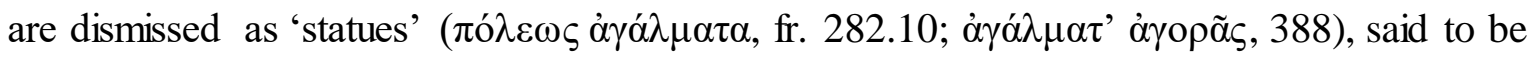
little help in war (fr. 282.19-21;388-9) and compared to others who are better suited to

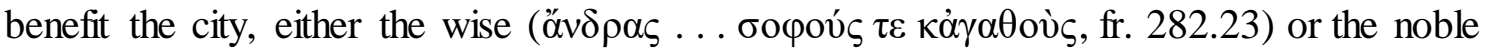

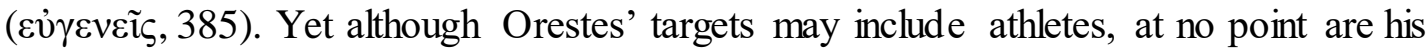
criticisms directly levelled at them. ${ }^{47}$ Rather the lines are appropriate to Orestes' general discourse on the need to identify inner nobility and are less repetitive, and more in line with his train of thought, than some scholars have been willing to admit. On establishing a criterion for judging nobility, Orestes affirms that it is the noble men who are beneficial in public and private life. These are contrasted with those who are only outwardly good, that is

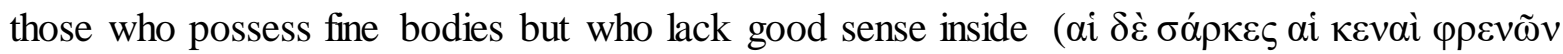

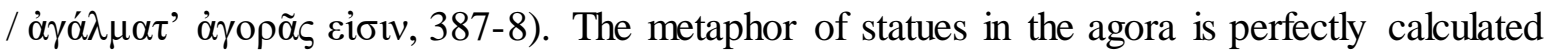
to evoke the image of hollow but outwardly beautiful bronze artworks. It also links back to the notion of poverty as a physical sign (372) and the correspondingly empty opinions of

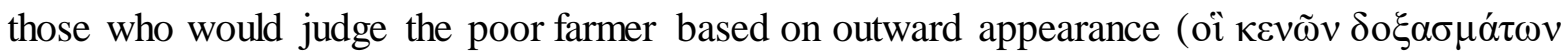
/ $\pi \lambda \eta ́ \rho \varepsilon 1 \varsigma \pi \lambda \alpha \nu \tilde{\alpha} \sigma \theta \varepsilon, 383-4)$.

In lines 388-90, Orestes returns to the topic of war that he touched on in $377-9$, yet these lines have a different purpose. He is no longer questioning the standard by which nobility should be measured, but rather defending the criteria he has now adopted: i.e. the primary importance of inner character over physical strength. He thus pre-empts an objection: surely it is the men with good bodies who are most useful to the city in war? The response is that it is not bodily strength that really matters, but inner courage, since a strong coward will

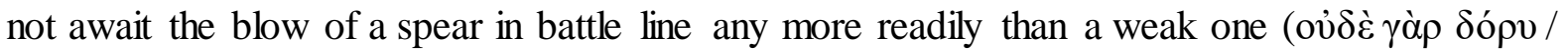

\footnotetext{
46 Pechstein (1998) 79-82; Larmour (1999) 63; Distilo (2012) 171-2.

${ }^{47}$ As noted by Slings (1997) 147.
} 
$\mu \tilde{\alpha} \lambda \lambda$ ov $\left.\beta \rho \alpha \chi i ́ \omega v ~ \sigma \theta \varepsilon v \alpha \rho o ̀ \varsigma \alpha \dot{\alpha} \sigma \theta \varepsilon v o v \tilde{\zeta} \mu \varepsilon \varepsilon^{\prime} \varepsilon 1,388-9\right)$. What is important is not the outer shell of

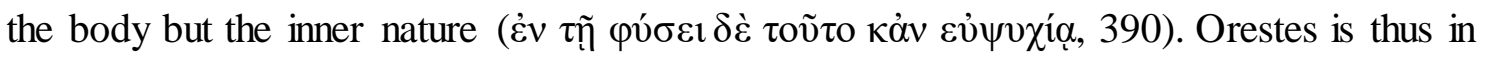
agreement with Tyrtaeus (fr. 12.1-9 West), who questioned whether athletic prowess, or even the stature and might of the Cyclopes, was genuinely equal to the rigours of combat.

Orestes' oration is not simply the ramblings of a contemplative yet irresolute young man. It is carefully prepared for by the earlier contrast between the outward appearance of the poor farmer and his heritage: the inner nobility now proven by his correspondingly noble conduct towards Orestes. The speech is itself coherent and follows a clear train of thought. In doing so, it sums up the major conclusions the audience should draw from the first third of the play: that nobility, though hereditary, is hard to identify because it cannot be measured by external finery or even the physique of the body beneath. The importance of these conclusions will become clear in the second part of the play, the 'recognition scene', to which we will now turn. It is at this point that Euripides combines the testing of character with that of identity.

\section{The Recognition Scene}

The prelude to the recognition serves to raise a dilemma: how is Orestes to be recognised? This is because the question of Orestes' nobility is closely linked to that of his identity. Orestes is the son of a king, Agamemnon, who was not only a man of great wealth but one who proved his nobility through his conquest of Troy. If Electra's nameless visitor has inherited the nobility of Agamemnon, then he must also be Orestes the son of Agamemnon. This in turn looks forward to the final section, the revenge, for if Orestes has inherited Agamemnon's nobility, then he will be able to bring vengeance on his father's killers. The difficulty is that, just as for his nobility, it is hard to establish a criterion with which to judge Orestes' identity. 
Unlike the farmer or Electra, Orestes appears a nominally noble man. He has come with a train of servants and baggage (393-4), which presages the chariot and Trojan servants of his mother. He is also in his prime physically, as is demonstrated by the frequent use of athletic imagery (and perhaps in performance by costume). He skins the hide of Aegisthus' sacrificial calf quicker than a runner could race two laps of a track (824-5). Orestes's supposed destination of Olympia is another hint at his athletic prowess (781-2). Electra's assumption that her brother will have the hair of a young athlete in the recognition scene (528) echoes this motif and prepares for her later declaration that Orestes, in killing Aegisthus, has gained a far greater victory than a mere runner at Olympia (862-4).

Yet on the other hand he also appears weaker than he should. As several critics have noted, Electra expects her brother to openly challenge Aegisthus and is disappointed when her expectations are not fulfilled. ${ }^{48}$ She complains of his tardiness, even though he is a young

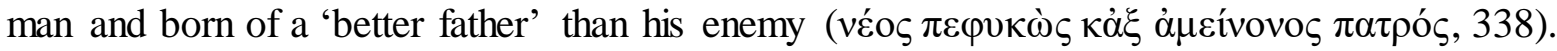
This echoes her refusal to believe that Orestes would return in secret (525-6). Yet, Orestes cannot reveal his identity and strength as the son of 'the better man' Agamemnon. As the disguised Orestes reminds her, and as she herself will admit, her brother is an exile with a price on his head and, though not without means, he lacks the necessary supporters to launch

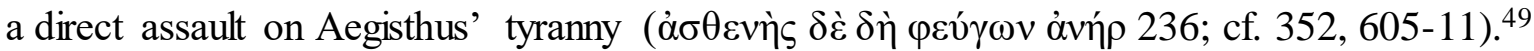
Like the farmer's poverty (cf. 38), Orestes's circumstances make him appear weaker than he actually is. His stealthy assault on Aegisthus has outraged some critics. ${ }^{50}$ Yet as Orestes has

\footnotetext{
48 Denniston (1939) xxvii; Lloyd-Jones (1961) 178; Basta Donzelli (1978) 126-7; Arnott (1981) 183; Wohl (2015a) 68-9; cf. Kovacs (1989) 68-9, who suggests that the contradiction between lines 336-8 and 524-5 is an argument for deletion of the latter; West (1980) 16-17 makes the case for retaining the lines.

${ }^{49}$ As is noted by Lloyd (1986) 11.

${ }^{50}$ E.g. Arnott (1981) 186-7: the 'sordid viciousness' of Aegisthus' murder; cf. Kitto (1939) 336; Tarkow (1981) 145; Morwood (1981) 366-7; Michelini (1987) 214. On the murder as perverted sacrifice see Zeitlin (1970) 6513.
} 
no support in Argos and because the tyrant is ringed with bodyguards, the old man rules out any other option (605-17). Euripides' intention here is not to highlight Orestes' inadequacy when compared to a heroic ideal, but rather to show, again, how appearances can be deceptive.

It is not surprising, then, that the farmer is sufficiently impressed by the appearance of Orestes to declare that he and Pylades seem noble.

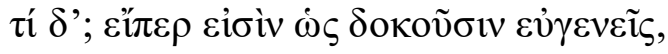

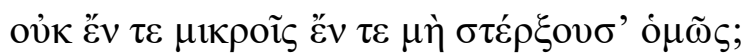

What then? If they are noble as they seem to be, they will be equally happy in reduced circumstances as in its opposite.

The farmer judges by appearance that they are good by birth and will therefore not look askance at his home, given that nature is, as the farmer has demonstrated, unchanging. Yet the old man, like Orestes, is aware that things may not be as they seem:

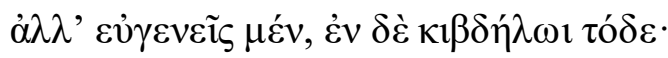

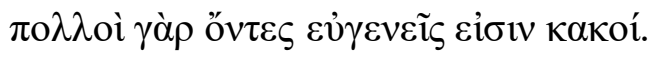

Well they are noble, but this is a matter of uncertainty; for many who are noble are bad.

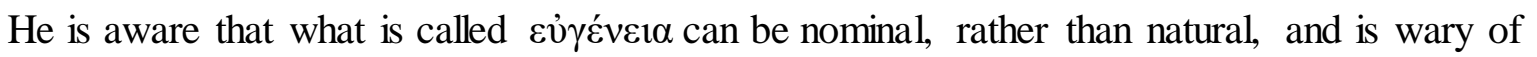

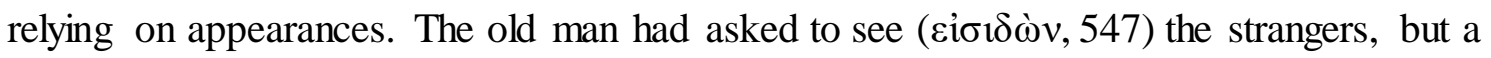
closer inspection is needed to verify the truth. This caution recalls the difficulties he has had in establishing Orestes's presence and identity, which is in fact the reason why he wishes to speak to Electra's visitors. Electra had also previously admitted that she would be unable to recognise Orestes by sight ( $\varepsilon i \sigma 1 \delta o \tilde{v} \sigma \alpha 283$ ). The only person who can identify him is the old 
man. Nevertheless, at first sight the old man is unable to recognise Orestes and is forced to look more carefully. Once again first appearances are unreliable, and the challenge is to find a visible sign that can be trusted.

Scholars such as Bain and West have assumed that the recognition scene (518-44) is an irrelevant parody of Aeschylus and much of the debate concerning its authenticity has centred on the question of whether Euripides could have gone so low as to make fun of his great predecessor. ${ }^{51}$ Yet, as Halporn has demonstrated, the scene does not closely conform to any generally recognised definition of parody: there seem to be deliberate echoes of Aeschylus' play here, though there is little to suggest that humour was the principal object of such a comparison. ${ }^{52}$ The purpose of these lines, I suggest, is rather to confirm what has already been established: the inherent difficulty in determining Orestes' identity and nature. The recognition scene highlights the problems of identifying Orestes by means of tokens (hair, footprints and clothing, 528-37). Her rejection of these three signs proposed by the old man recall Orestes' rejection of the standard criteria for nobility (wealth, poverty and physique). Here we see that the two problems are interlinked and, in each case, a better method of testing is required.

While Orestes had proposed a man's character and associations as the true yardstick for nobility, the old man discovers the scar. In ultimately revealing Orestes' identity, it allows inferences to be made simultaneously regarding his character. Euripides' mark evokes the scar of Odysseus (Od.19.386-466). Some have argued that this intertextual reference is intended to call into question the nobility of Orestes. For Halporn, the scar is a negative

\footnotetext{
${ }^{51}$ Bain (1977) 111: the author of 518-44 did 'not greatly [care] whether what he wrote was integrated into its dramatic context or comprehensible to an audience in a theatre.' West (1980) 18-19: the criteria proposed by the old man 'have no roots in the present context but are dragged in solely to be ridiculed. No one disputes this.'

${ }^{52}$ Halporn (1983) 11.
} 
motif, one that, unlike Aeschylus' garment, deliberately fails to mark any connection between brother and sister and 'removes the sense of familial and domestic ties from the play entirely. ${ }^{53}$ Tarkow and Goff have compared the differing accounts of how the heroes receive their respective scars and come to similar conclusions: Odysseus is wounded by a boar during a hunt, while Orestes falls over rather pathetically while chasing a fawn indoors. ${ }^{54}$ Likewise, for Wohl, these 'literary allusions and theatrical clichés' reveal Orestes's social status as 'empty, based on the accident of birth and devoid of ethical content.' 55

Yet such a comparison between the heroes is unreasonable and it is unlikely that Euripides would have expected his audience to draw one in those terms. Odysseus was a young man (19.410) at the time of the hunt and, over twenty years later, a mature man when the scar is found by Eurycleia. Orestes, who in the Odyssey has recently accomplished his revenge, is a model for the youthful and insecure Telemachus. ${ }^{56}$ Odysseus' boar hunt and journey to meet his grandfather, Telemachus' voyage to Pylos and Sparta, and Orestes' violent return to Argos all come under the same category of rites of passage for youths. Orestes would have had to have been unusually precocious to have joined a hunting expedition before he left Argos.

Why then does Euripides borrow the seemingly inappropriate motif of the scar? The answer lies in the term used to describe the mark for which the old man is looking:

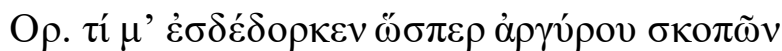

\footnotetext{
${ }^{53}$ Halporn (1983) 113.

54 Tarkow (1981) 146 'the mythical foil which the scar suggests... serves to remind us of the essentially unheroic fellow Euripides is portraying in Orestes'. Goff (1991) especially 262: Electra 'probes . . the very concept of traditional heroism'; cf. O’Brien (1964) for a similarly unflattering comparison between Orestes and Perseus.

55 Wohl (2015b) 75.

56 Od. 1.296-305, 3.199-200, see Olson (1995) 24-42.
} 


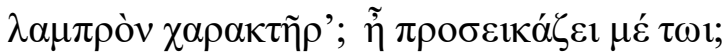

Orestes: Why is he looking at me as though he were looking at a bright mark

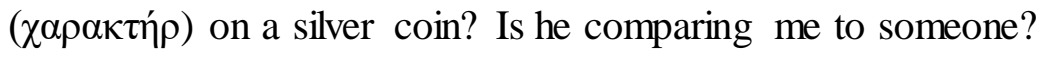

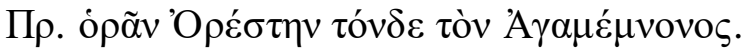

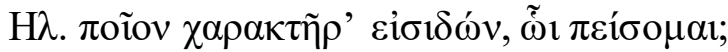

Old man: I say that I am looking at Orestes the son of Agamemnon.

Electra: What sort of mark ( $\chi \alpha \rho \alpha \kappa \tau \eta ́ p)$ have you seen that that I can trust?

As line 558 makes clear, the metaphor is drawn from methods of establishing the purity of precious metals in coins by affixing an official mark of state coinage. Like a mark on coins, a scar is a permanent impression of a cut or blow onto the body. The old man is acting in a

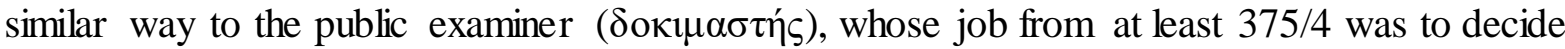
whether suspect coins brought to him at his seat in the market were genuine or counterfeit. ${ }^{57}$ Such a metaphor suggests that the scar is a sign both of Orestes's identity and his moral

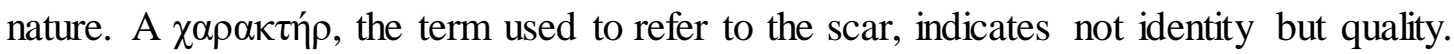

The scar, like the $\chi \alpha \rho \alpha \kappa \tau$ $\rho$, is also markedly different from the other tokens dismissed earlier. It is not placed on the body, like a garment, nor is it separate from the body, like footprints or a shorn lock, but it is part of the body and yet a sign of quality within.

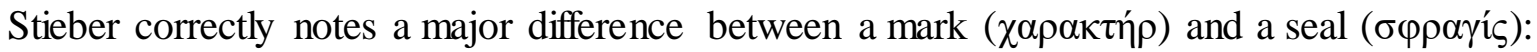
the seal imprints a sign upon another object to mark possession or identity or may act as a

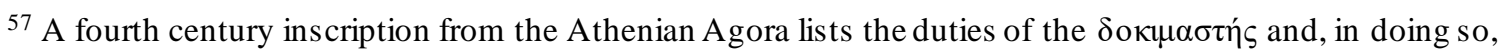

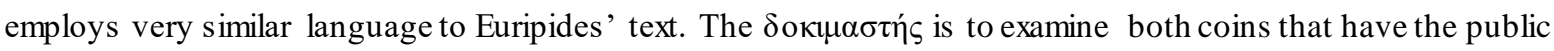

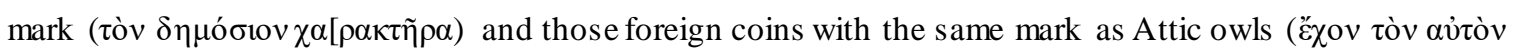

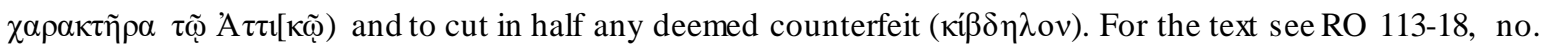
25.
} 
token in itself, as in Sophocles' Electra (1223). ${ }^{58}$ The token ( $\left.\sigma 0 ́ \mu \beta \mathrm{o} \lambda \mathrm{ov}\right)$, the term used by

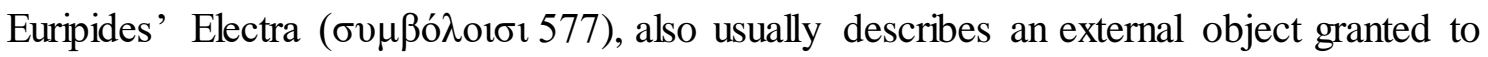
another as a proof of contract or a sign of identity. These include clay plaques that have been deliberately cut in half: a description that would fit the lock and even the garment well. ${ }^{59}$ Alternatively, $\sigma u ́ \mu \beta 0 \lambda$ ov may refer to a password which may be discovered and used to disguise an enemy as a friend, as in the Rhesus (573). The scar, on the other hand, cannot be separated from Orestes and so misused.

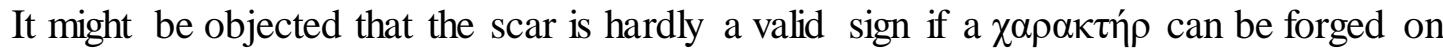
coins. Cropp characterises this metaphor as a traditional 'comparison between deceptive human character and counterfeit metal or coinage'. ${ }^{60}$ This would seem to complement Goff and Tarkow's belief that the scar in some way 'hints at Orestes' less than heroic stature'. ${ }^{61}$ A similarly negative interpretation of the motif of 'coins and character' is provided by Stieber. For her the significance of the motif is in demonstrating the difficulty of identifying human character 'just as it is impossible to gauge the value of a coin by its $\chi \alpha \rho \alpha \kappa \tau \eta ́ p$ alone: the coin may in fact be fraudulent. ${ }^{92}$ Yet, even allowing for forgeries in daily life, it is still possible to read the metaphor more positively. The $\chi \alpha \rho \alpha \kappa \tau \eta ́ p$, once affixed to metal, now provides a clear indication of worth that is normally accepted, even if further tests may be necessary should a dispute arise. The Athenian owl mark, as Ober has shown, became a brand that

\footnotetext{
${ }^{58}$ Stieber (2009) 256, citing Eur. IA 155-6, Or. 1188 and fr. 781.223. However, the seal is not, as Stieber claims, a more reliable sigh than the mark in regard to quality: contrast Soph. Trach. 614-15 where the imprint of the seal points to the clothes sent to Heracles as the possessions of Deianeira,but fails to indicate their lethal qualities and indeed serves to deceive him.

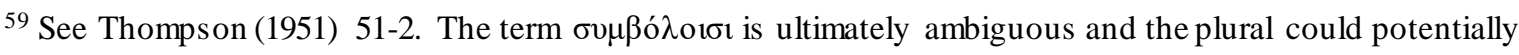
encompass all or only one item: see Bain (1977) 106.

${ }^{60}$ Cropp (2012) 182.

${ }^{61}$ Cropp (2012) 176-7; cf. Tarkow (1981) 151 '[Orestes'] heroic mettle is as counterfeit as is the coin in the metaphor'.

${ }^{62}$ Stieber (2009) 255.
} 
'stood for solid quality' throughout the Eastern Mediterranean. ${ }^{63}$ Orestes' scar indicates that he is the son of Agamemnon and that, as such, he should have the strength to kill Aegisthus, even if this will only be confirmed through the final trial that is the killing itself.

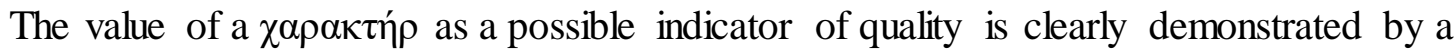
passage in the Medea:

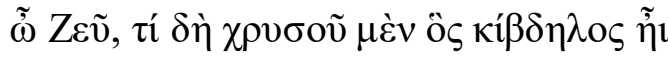

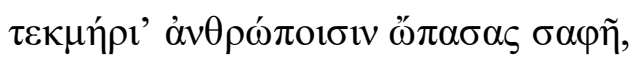

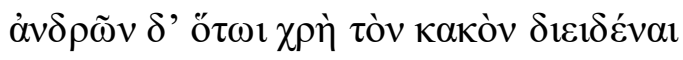

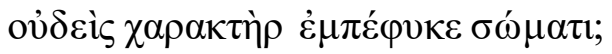

Oh Zeus, why have you given clear signs to mortals for gold to tell when it was

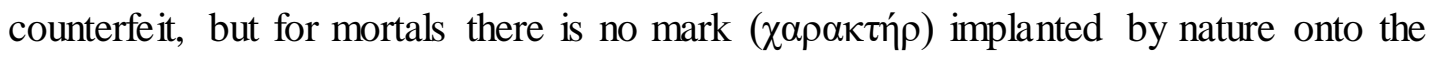
body by which it is possible to identify a bad one.

The image of the counterfeit ( $\kappa i ́ \beta \delta \eta \lambda ం \varsigma$ ) gold resembles the old man's concerns that Orestes' character may be similarly corrupt ( $\dot{\varepsilon} v \delta \grave{\varepsilon} \kappa \iota \beta \delta \eta \dot{\lambda} \lambda \omega \iota \tau$ tó $\delta \varepsilon, 550)$. While there is no mark of quality for people, there are methods of assessing the purity of gold that include the $\chi \alpha \rho \alpha \kappa \tau \eta ́ p$. Marks on coins, it is assumed, can normally be trusted.

Medea wishes a sign would naturally occur on human bodies $(\dot{\varepsilon} \mu \pi \varepsilon \dot{\varepsilon} \varphi v \kappa \varepsilon)$ : a choice of

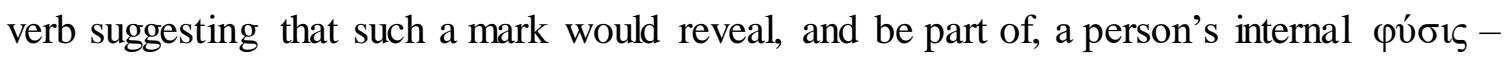

\footnotetext{
63 Ober (2008) 227.

${ }^{64}$ Stieber (2009) 259 is aware of the difficulties this passage poses for her argument and tries to reconcile the two: "if, in the best of worlds, "character", emanating from within, gravitated to the surface to reveal itself as opposed to being imposed artificially by external forces from without, it could be trusted, whetherit appears on a coin or a human body' [my emphasis]. Yet Medea explicitly contrasts coins and human bodies and implies that different rules apply in each case.
} 
whether good or, in this case, bad. Similarly, Theophrastus states that it is the nature of touchstones to reveal the natural quality $(\varphi v ́ \sigma i \varsigma)$ of precious metals. ${ }^{65}$ It is thus that part of the nature of metals that admits of such assaying and stamping that she wishes were replicated in human beings. She does not deny that additional signs (such as that provided by the

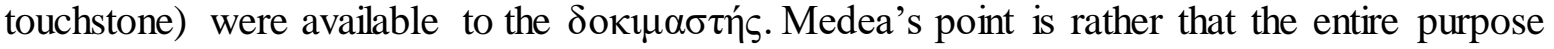
of the $\chi \alpha \rho \alpha \kappa \tau \eta ́ p$ on coins is to act as a guarantee of quality and that, in an alternative world, a mark of that kind would be a generally reliable (though she does not say infallible) indicator of human worth. For the same reason, Electra asks the old man to produce such a mark to justify his identification of Orestes (572). Although in most cases people do not have the mark of Medea's fantasy world, Orestes is the exception. The scar is the external mark

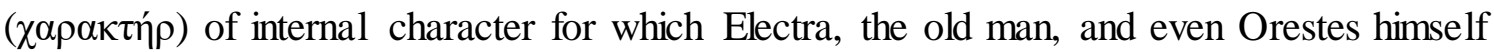
have been looking.

The mark is also bright ( $\lambda \alpha \mu \pi \rho$ òv $\chi \alpha \rho \alpha \kappa \tau \tilde{\eta} \rho ', 559)$. This brightness is obviously appropriate to precious metal, yet it has a double meaning as an adjective commonly applied to an elite, either a natural one defined by birth and excellence, or a nominal one defined by

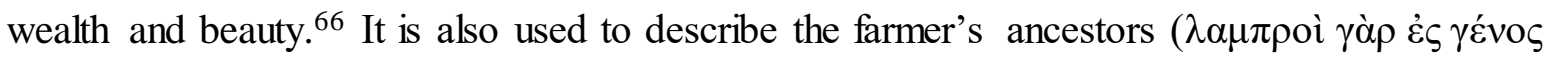
$\gamma \varepsilon, 37)$, the lustre of whose birth was obscured by poverty. The scar of Orestes thus appears as an indicator of the excellence of Orestes' bloodline. Medea, in the passage cited above, is most concerned with discovering bad character, as she has been lately deceived by Jason. Yet a test for metals can as easily be used to describe the identification of good nature. Such is the purpose of the touchstone in the Theognidea:

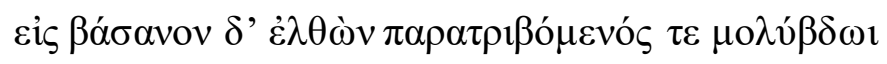

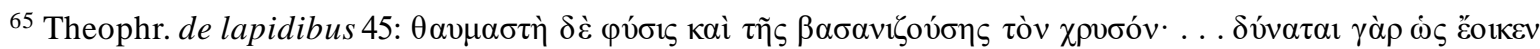

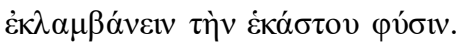

66 Supp. 222; Tro. 992; frr. 184; 282.10; 683a.
} 


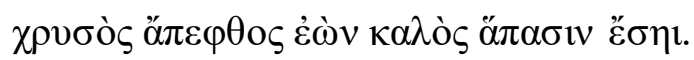

Once you have gone to the touchstone and are rubbed next to lead, as refined gold you will appear fine to all.

(1105-6, cf. 415-18, 1164e-h)

Euripides may have had this or parallel passages in mind. In an unknown Euripidean tragedy, a character is similarly urged to prove his mettle in good and bad fortune:

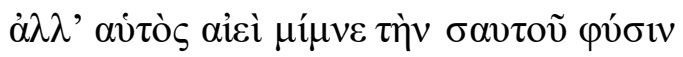

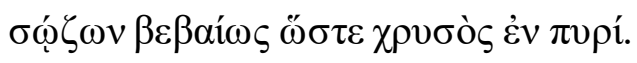

But remain yourself always the same, preserving your nature forcefully as gold in fire.

(fr. 963.4-5)

Here the ideal is that the best men should resemble the highest quality metals in being free of corruption and, moreover, remain so even under pressure. This final test of Orestes' quality will come in the concluding part of the play, the act of revenge.

\section{The Revenge}

Before Orestes departs for his deadly rendezvous with Aegisthus, Electra tells him that it is

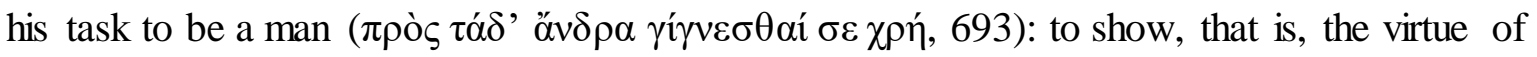

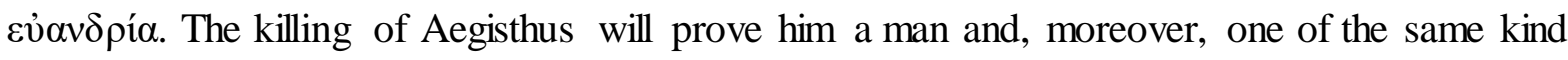
as his father. The hero and his friends celebrate the new victory as an achievement that continues the run of successes begun by Agamemnon at Troy.

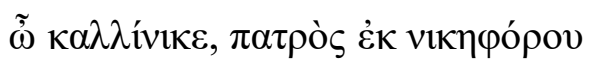

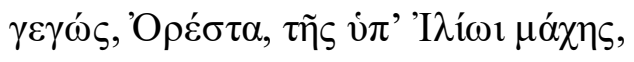

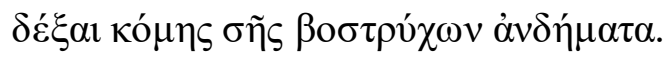

Oh Orestes, glorious in victory, born from a father victorious in the battle at Ilium, receive these garlands for your locks of hair. 
The blood of Agamemnon does indeed run in his son's veins. The assassination has fulfilled Electra's initial expectations of Orestes based upon the previous excellence of his father:

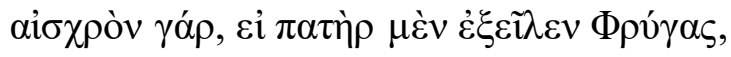

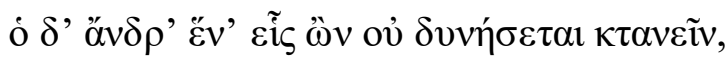

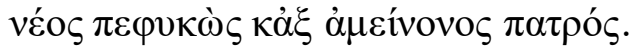

For it will be shameful, if his father conquered the Phrygians, but he is not able to kill one man one-to-one, though being young and born from a better father.

It is now clear that he is noble in nature as well as status and wealth.

The use of athletic imagery emphasises the importance of good birth in winning trials of combat. In honouring his boy victors, Pindar frequently stresses the earlier achievements of the athlete's family. Such a tradition provides these youths with a significant advantage in the gymnastic trials that will see them pass from adolescence into manhood. ${ }^{67}$ The eventual victory is the natural continuation of a family tradition and further vindication of the inherent strength of the clan. The Theban boy runner Thrasydaeus in Pythian 11 is said to have cast another wreath onto the ancestral hearth, capping two previous triumphs (possibly by his grandfather). ${ }^{68}$ It is not surprising that Pindar juxtaposes his achievement with the myth of Orestes. In Euripides, by contrast, the killing of Aegisthus is more glorious, according to Electra, than an unproductive running

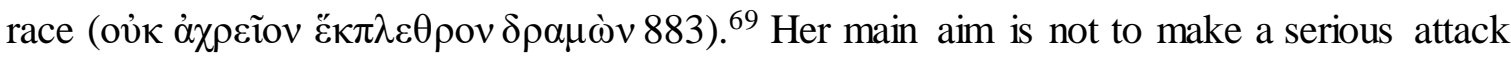
on athletics, which would undermine the comparison between Orestes and athletic victors,

\footnotetext{
${ }^{67}$ See e.g. Nem. 3.40-2; 4.78-80, 5.40; Isthm. 6.57-65, 8.71-2; on the transition from adolescence to adulthood, see Burnett (2005) 48-51.

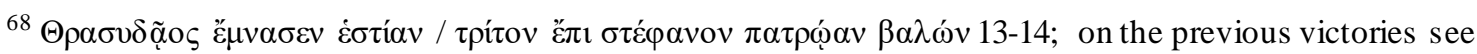
Finglass (2007) 3 .

${ }^{69}$ Cf. 862-4; otherathletic references: runner 824-5, 953-6; crown 854, 872, 882; see Egli (2003) 229-33.
} 
but to stress the superiority of Orestes' victory above and beyond what is normally regarded as one of the highest human achievements. ${ }^{70}$ Both Thrasydaeus and Orestes have lived up to their family traditions, but Orestes has won his victory in actual combat.

Some have been unwilling to take Electra's statement at face value. We have become so used to identifying Orestes' unheroic aspects that we are unable to accept her evaluation of

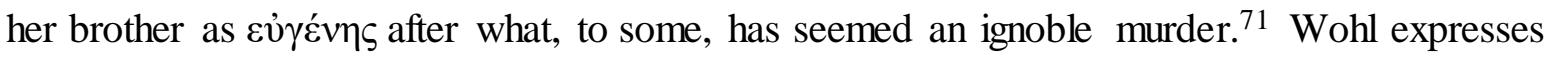
this feeling of disappointment: 'we ourselves have bartered away the possibility of non-elite agency when we mistake this worthless aristocrat for a "dear treasure" and this "weak" character for a tragic protagonist.' The universal acclamation of Aegisthus' former servants (854-5) should not deceive us, says Wohl. Orestes' subjects believe in his triumph 'so we won't have to, they pay the political price while we enjoy the spectatorial profit'. ${ }^{72}$ The play has lost in its final scene what Edith Hall has termed a 'utopian tendency' to express ideas that are 'vastly more politically advanced than the society which produced Greek tragedy'. ${ }^{73}$

Wohl's disappointment, however, betrays the attitudes and concerns of twenty-first century liberal academics, not fifth-century BC Greeks. As Wohl admits, none of the characters treats the killing of Aegisthus as anything other than a noble and just act. She assumes that the murder is self-evidently wrong because Orestes tricks his victim and strikes him in the back, and so transforms the deed into a perverted and impious sacrifice. But is this assumption really justified? As Lloyd has noted, the death of an enemy at a sacrifice could as easily be taken as evidence for divine sanction or even connivance in a just killing. ${ }^{74}$ Sacrifices and festivals presented good opportunities for the assassination of tyrants: the

\footnotetext{
${ }^{70}$ For the passage as a critique of athletics, see Arnott (1981) 188-90.

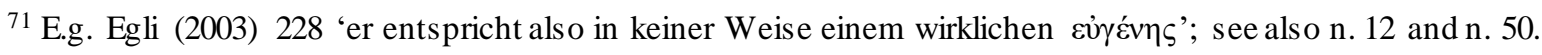

72 Wohl (2015a) 70, 72-3.

${ }^{73}$ Hall (1997) 125.

${ }^{74}$ Lloyd (1986) 16 cites examples from tragedy, including Soph. Trach. 753-66 and Eur. HF 922-30.
} 
Athenian tyrannicides murdered Hipparchus during the Panathenaea, yet they were still lauded as heroes. ${ }^{75}$ Trickery was similarly used by Greek horsemen at the battle of Himera to strike down the Carthaginian general while he was in the act of sacrificing to Poseidon. Far from committing a sacrilegious act, Gelon had saved the Greeks of Sicily. This story, told by Diodorus $(11.21 .4,22.1)$, is partially corroborated by Herodotus $(7.167)$, who states that Hamilcar threw himself onto the sacrificial fire, an act which led to the establishment of hero cults in Sicily and Carthage.

It is also not necessarily immoral to use cunning against a villain. However welcoming Aegisthus may be to unidentified strangers, he is himself a murderer and usurper. Trickery need not imply cowardice either. In fact, Orestes, as the messenger relates (844-7), very nearly meets the same fate as the Harmodius and Aristogeiton, who were respectively struck down and captured by Hipparchus' bodyguards. By contrast, Orestes in the Andromache is accompanied by a band of assailants, while his victim, Neoptolemus, fights alone on the sacrificial altar (1114-24). Because of this, the messenger explicitly views as the killing a shameful act (1161-5), even if one sanctioned by a vengeful Apollo. In the Electra, however, it is Orestes and Pylades who manfully ( $\alpha \nu \delta \rho \varepsilon i ́ \alpha \varsigma$ ' $\left.\delta^{\prime} \pi \circ, 845\right)$ stand alone against Aegisthus' slaves.

A negative reading of Orestes' actions in the Electra is still possible, but it is not inevitable; indeed, such an interpretation finds no support from within the text itself. Nevertheless, Orestes' inheritance is by no means entirely positive. The matricide is undoubtedly a crime and this action, as Cropp and others have noted, overshadows Orestes' victory parade. ${ }^{76}$ As Castor will acknowledge at the end of the play, Orestes and Electra will

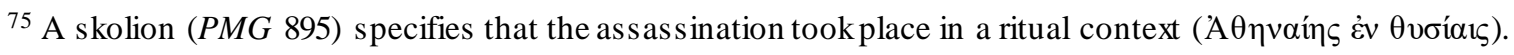

${ }^{76}$ Cropp (2012) 203.
} 


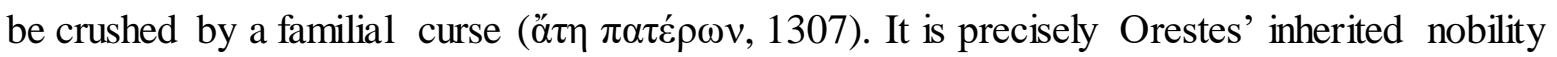
and bloodline that will tragically force him to avenge his father by killing his mother. Nobility, as we have seen, is destructive for the hero himself, and not merely his enemies.

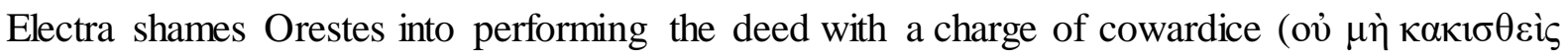

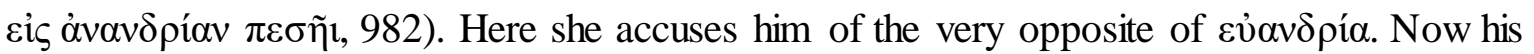
courage and strength are required to perform an act that is entirely impious. It is against

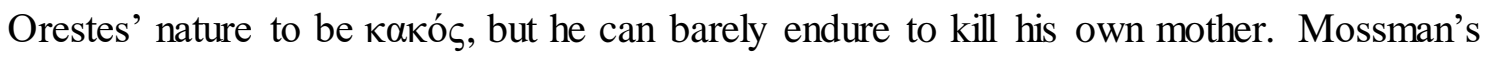
comment is apt: 'I am inclined to think that the term 'anti-heroic' is something of a red herring ... What is wrong with Electra and Orestes is not that they are not heroic, but that their heroism is horribly misdirected.' 77

The nobility of Orestes becomes an essential part of the tragedy because it is the very thing that makes the killing of Clytemestra both inevitable and heinous. If Orestes is the son of Agamemnon, he is also the son of Clytemestra. In the final episode of the play, it is the familial relationship between Orestes and Clytemestra that is stressed, rather than Agamemnon. Orestes expresses his reluctance to commit matricide as an unwillingness to kill

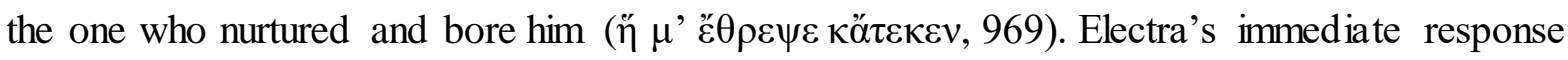

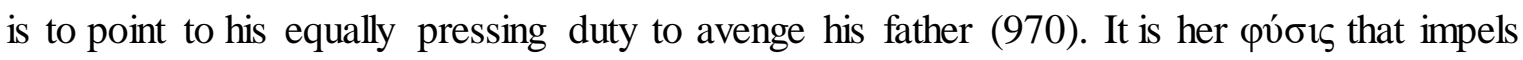
her and Orestes towards the murder, as Clytemestra unwittingly reveals: she is by nature

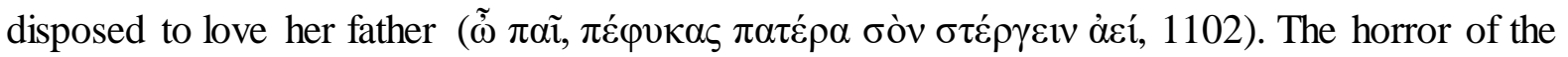
matricide only becomes fully apparent through the recognition that Clytemestra gave birth to her killers: the siblings are only too aware of this by the exodus, where it is stressed three

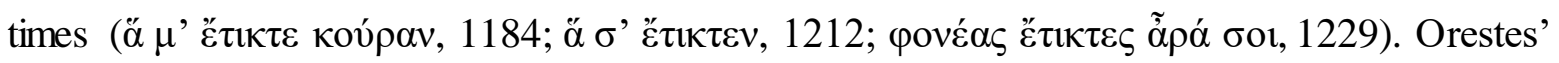

\footnotetext{
${ }^{77}$ Mossman (2001) 376-7.
} 
heritage both enables the glorious victory over Aegisthus and, by the same token, draws him inevitably to the act of parricide.

\section{Conclusion}

Aeschylus had created a tragedy of interfamilial strife caused by pollution and the family curse, which called for revenge from generation to generation. Euripides tells the same tragic story and creates the same effect in a startlingly original way. He has crafted his plot not around the crimes of previous generations, but rather the difficulties in identifying inherited nobility or moral excellence. The farmer demonstrates through his poverty and noble actions that wealth does not equal worth. A better criterion is needed to prove that Orestes is indeed the son of Agamemnon and that he has inherited from his father the family traits needed to win victory. After Electra's rejection of the old man's tokens, the final test, the scar, proves Orestes' identity and, by extension, his nobility as surely as a mark upon a coin. This heritage is both a boon and a curse: it means that the final blow is struck against Orestes' own family, the very source of strength that had proved so potent against the clan's external enemies. Like Aeschylus, Euripides traps Orestes with his own bloodline and uses it to propel his hero towards matricide and the consequences of kin-killing: pollution and exile.

Euripides' Electra is a play of great subtlety and careful artistry. Some critics may object that it is too clever; yet this drama is at least intelligible, if we are willing to understand it on its own terms.

Bibliography

G.W. Arnott, 'Double the vision: a reading of Euripides' Electra', G\&R 28 (1981) 179-192.

D. Bain, '[Euripides] Electra 518-44', BICS 24 (1977) 104-16.

G. Basta Donzelli, Studio sull'Elettra di Euripide (Catania 1978).

A.P. Burnett, Pindar's Songsfor the Young Athletes of Aegina (Oxford 2005).

J. Carlevale, 'Physis and Freedom in Sophocles' Philoctetes',Arion 8 (2000) 26-60. 
D.J. Conacher, 'Nomos and Physis in Euripides', in Celebratio: Thirtieth Anniversary Essays at Trent University, eds. J.P. Bews, I.C. Storey and M.R. Boyne (Peterborough 1998) 13-20.

N. B. Crowther, Athletika: Studies on the Olympic Games and Greek Athletics (Hildesheim 2004).

M.J. Cropp, Euripides, Electra (Oxford 2012, 2nd edn).

M. Davies, 'Euripides' Electra: The Recognition Scene Again', CQ 48 (1998) 389-403.

J.D. Denniston, Euripides, Electra (Oxford 1939).

N. Distilo, Commento Critico-Testuale all' Elettra di Euripide (Padua 2012).

K.J. Dover, Greek Popular Morality in the Time of Plato and Aristotle (Oxford 1974).

F. Egli, Euripides im Kontext zeitgenössischerintellektueller Strömungen (Munich 2003).

T.M. Falkner, 'Coming of age in Argos: physis and paideia in Euripides' Orestes', CJ 78 (1983) 289-300.

P.J. Finglass, Pindar Pythian Eleven (Cambridge 2007).

E. Fraenkel, Aeschylus, Agamemnon (Oxford 1950).

R.L. Gallagher, 'Making the stronger argument weaker: Euripides Electra 518-44', CQ 53 (2003) 405-14.

G. Gellie, 'Tragedy and Euripides' Electra', BICS 28 (1981) 1-12.

B. Goff, 'The sign of the fall: the scars of Orestes and Odysseus', CA 10 (1991) 259-67.

B. Goff, 'Try to make it real compared to what? Euripides Electra and the play of genres', in Euripides and Tragic Theatre in the Late Fifth Century, ed. M. Cropp et al. (Stipes 2000) 93-105

S. Goldhill, 'Rhetoric and relevance: interpolation at Euripides' Electra 367-400', GRBS 27 (1986a) 157-71.

S. Goldhill, Reading Greek Tragedy (Cambridge 1986b).

W.K.C. Guthrie, A History of Greek Philosophy III (Cambridge 1969).

E. Hall, 'The sociology of Athenian tragedy', in The Cambridge Companion to Greek Tragedy, ed. P. Easterling (Cambridge 1997) 93-126.

J. W. Halporn, 'The skeptical Electra', HSCP 87 (1983) 101-18.

H.D.F. Kitto, Greek Tragedy. A Literary Study (London 1939).

B.M.W. Knox, The Heroic Temper: Studies in Sophoclean Tragedy (Berkeley 1964).

D. Kovacs, 'Euripides Electra 518-44: further doubts about genuineness', BICS 36 (1989) 67-78.

D. Larmour, Stage and Stadium (Hildesheim 1999).

M. Lloyd, 'Realism and character in Euripides' Electra', Phoenix 40 (1986) 1-19.

H. Lloyd-Jones, 'Some alleged interpolations in Aeschylus' Choephori and Euripides' Electra', CQ 11 (1961) 171-84

A. Mau, 'Zu Euripides Electra', in Commentationes Philologiae in Honorem Theodori Mommseni (Berlin 1877) 291-301.

A. N. Michelini, Euripides and the tragic tradition (Madis on 1987).

J. Morwood, 'The Pattern in the Electra of Euripides', AJP 102 (1981) 362-70.

J. Mossman, 'Women's speech in Greek tragedy: the case of Electra and Clytemnestra in Eurpides' Electra', CQ 51 (2001) 374-84.

J. Ober, Democracy and Knowledge: Innovation and Learning in Classical Athens (Princeton 2008).

M.J. O’Brien, 'Orestes and the gorgon: Euripides' Electra', AJP 85 (1964) 13-39.

S.D. Olson, Blood and Iron: Stories and Storytelling in Homer's Odyssey (Leiden 1995).

N. Pechstein, Euripides Satyrographos: ein Kommentar zu den Euripideischen Satyrspielfragmenten (Stuttgart 
1998).

D. Raeburn, 'The significance of stage properties in Euripides' Electra', G\&R 47 (2000) 149-68.

M.D. Reeve, 'Interpolation in Greek Tragedy III', GRBS 14 (1973) 145-71.

P.W. Rose, 'The myth of Pindar's first Nemean', HSCP 78 (1974) 145-75.

S.R. Slings, 'Notes on Euripides' Electra', Mnemosyne 50 (1997) 131-64.

M. Stieber, 'Coins and character in Euripides', in The Play of Texts and Fragments, ed. J.R.C. Cousland and J.R. Hume (Leiden 2009) 255-72.

T.A. Tarkow, 'The scar of Euripides: observations on a Euripidean innovation', RhM 124 (1981) 143-153.

H.A. Thompson, 'Excavations in the Athenian Agora: 1950', Hesperia 20 (1951) 45-60.

I. Torrance, Metapoetry in Euripides (Oxford 2013).

E. Van Emde Boas, Language and Character in Euripides' Electra (Oxford 2017).

P. Vellacott, Ironic drama : a study of Euripides' method and meaning (Cambridge 1975).

U. von Wilamowitz-Moellendorff, Analecta Euripidea (Berlin 1875).

T. B. L. Webster, Greek tragedy (Oxford 1971).

M.L. West, 'Tragica IV', BICS 27 (1980) 9-22.

V. Wohl, 'How to recognise a hero in Euripides' Electra', BICS 58 (2015a) 61-76.

V. Wohl, Euripides and the Politics of Form (Princeton 2015b).

F. Yoon, The Use of Anonymous Characters in Greek Tragedy (Leiden 2012).

F.I. Zeitlin, 'The Argive Festival of Hera and Euripides' Electra', TAPA 101 (1970) 645-64. 